with cystic fibrosis. Am J Respir Crit Care Med 1998; 157: 1951-1958.

5 Hirshberg B, Biran I, Glazer M, Kramer MR. Hemoptysis: etiology, evaluation, and outcome in a tertiary referral hospital. Chest 1997; 112: 440-444.

6 Crocco JA, Rooney JJ, Fankushen DS, DiBenedetto RJ, Lyons HA. Massive hemoptysis. Arch Intern Med 1968; 121: 495-498.

7 Håkanson E, Konstantinov IE, Fransson SG, Svedjeholm R. Management of life-threatening hemoptysis. $\mathrm{Br} J$ Anaesth 2002; 88: 291-295.
8 Jean-Batiste E. Clinical assessment and management of massive hemoptysis. Crit Care Med 2000; 28: 1642-1647.

9 Albert RK, Spiro SG, Jett JR, eds. Clinical Respiratory Medicine. 2nd Edn. Philadelphia, Pennsylvania, Mosby 2004; pp. 253-254.

10 Dweik RA, Stoller JK. Role of bronchoscopy in massive hemoptysis. Clin Chest Med 1999; 20: 89-105.

11 Garzon AA, Cerruti MM, Golding ME. Exsanguinating hemoptysis. J Thorac Cardiovasc Surg 1982; 84: 829-833.

DOI: $10.1183 / 09031936.00080108$

\title{
Mortality predictive capacity of the 6-min walk distance
}

\section{To the Editors:}

In a recent issue of the European Respiratory Journal we read with interest the article by COTE et al. [1] on the capacity of the 6-min walk distance to predict mortality in chronic obstructive pulmonary disease patients. We noted a striking difference between the cut-off value reported by COTE et al. [1], corresponding to $350 \mathrm{~m}$, and a cut-off value previously reported as the mortality predictor in patients with idiopathic pulmonary fibrosis, which was $207 \mathrm{~m}$ [2].

Even considering the obvious diversities between the two diseases, such a difference is quite surprising. The two populations cannot be compared by forced expiratory volume in one second values because such data are lacking in the article by LEDERER et al. [2], but in both studies there are the data concerning forced vital capacity (FVC). Thus, we are permitted to compare the lung function by this parameter, where a remarkable difference can also be found: COTE et al. [1] reported a mean FVC value of $72.7 \pm 21 \%$ predicted, whereas LEDERER et al. [2] reported a mean value of $51 \pm 17 \%$ pred. The mortality rates were approximately two-fold in the study by COTE et al. [1] and four-fold in the study by LEDERER et al. [2]. In particular, the mortality rates recorded by LEDERER et al. [2] were significantly lower in the fourth quintile, patients walking 314-395 m, which included the allocated $350 \mathrm{~m}$ cutoff reported by COTE et al. [1].

As physicians currently working in a pulmonary rehabilitation setting we would like to learn more about the prognostic significance of the distance walked during the 6-min walk distance test in different respiratory diseases, which was not discussed in the study by COTE et al. [1].

\section{G.G. Riario Sforza and C. Incorvaia}

Pulmonary rehabilitation, Istituti Clinici di Perfezionamento, Milan, Italy.

\section{STATEMENT OF INTEREST}

None declared.

\section{REFERENCES}

1 Cote CG, Casanova C, Marín JM, et al. Validation and comparison of reference equations for the 6-min walk distance test. Eur Respir J 2008; 31: 571-578.

2 Lederer DJ, Arcasoy SM, Wilt JS, D'Ovidio F, Sonett JR, Kawut SM. Six-minute-walk distance predicts waiting list survival in idiopathic pulmonary fibrosis. Am J Respir Crit Care Med 2006; 174: 659-664.

DOI: $10.1183 / 09031936.00074408$

\section{From the authors:}

We have read with interest the observations by G.G. Riario Sforza and C. Incorvaia regarding the differences in the threshold values used to predict mortality that were provided by LEDERER et al. [1] for patients with idiopathic pulmonary fibrosis (IPF) and those that were reported for patients with chronic obstructive pulmonary disease (COPD) [2].

First, G.G. Riario Sforza and C. Incorvaia correctly point out that LEDERER et al. [1] quote a threshold of $207 \mathrm{~m}$ as being more specific for waiting-list mortality at 6 months but, in the discussion, LEDERER et al. [1] also state that the 350-m cut-off remained more sensitive for waiting-list mortality, a value that is very close to the one we reported [2].

Secondly, G.G. Riario Sforza and C. Incorvaia show surprise about the difference in mortality between the patients with IPF and those with COPD in our study. This has several likely explanations. To begin with, the patients reported by LEDERER et al. [1] were all on the waiting list for transplantation due to IPF, whereas ours were patients with different severity of COPD attending regular clinics, that is to say, healthier [2]. Furthermore, LEDERER et al. [1] do not mention the use of corticosteroids or immunosuppressants in their patients but it is very likely that patients with such severity of IPF may have been on agents capable of inducing muscle dysfunction. Finally, patients with COPD, even on transplant lists, have a better prognosis than patients with IPF or other underlying disease, thereby making direct comparisons difficult. 
Thirdly, G.G. Riario Sforza and C. Incorvaia request more information about the specific prognostic significance of the 6-min walk distance (6MWD) in COPD as the topic was not discussed in our paper. The specific goal of our study was to compare the behaviour of different predictive equations with the raw $6 \mathrm{MWD}$ value in metres and not to analyse the predictive value of the 6MWD per se. We have already published two studies that can help with the specific question [3,4]. The study by PINTO-Plata et al. [3] shows that the mortality for patients walking between $201-300 \mathrm{~m}$ was $40 \%$, very similar to that reported by LEDERER et al. [1]. This finding was also confirmed in a much larger cohort by CASANOvA et al. [4].

In conclusion, the literature suggest that patients with respiratory diseases that walk $>350 \mathrm{~m}$ have a relatively good prognosis and may not need to be followed as closely. Once patients walk $<350 \mathrm{~m}$ mortality increases linearly. The 6-min walk distance is an excellent and simple tool to follow progression and help determine outcome.

\section{C.G. Cote}

Medicine, Respiratory Disease Section, Bay Pines VA Hospital, Bay Pines, FL, USA.

\section{STATEMENT OF INTEREST}

None declared.

\section{REFERENCES}

1 Lederer DJ, Arcasoy SM, Wilt JS, D'Ovidio F, Sonett JR, Kawut SM. Six-minute-walk distance predicts waiting list survival in idiopathic pulmonary fibrosis. Am J Respir Crit Care Med 2006; 174: 659-664.

2 Cote CG, Casanova C, Marín JM, et al. Validation and comparison of reference equations for the 6-min walk distance test. Eur Respir J 2008; 31: 571-578.

3 Pinto-Plata VM, Cote C, Cabral H, Taylor J, Celli BR. The 6-min walk distance: change over time and value as a predictor of survival in severe COPD. Eur Respir J 2004; 23: 28-33.

4 Casanova C, Cote CG, Marin JM, et al. The 6-min walking distance: long-term follow up in patients with COPD. Eur Respir J 2007; 29: 535-540. 